\title{
Penetration and development of Meloidogyne enterolobii in resistant and susceptible Capsicum spp.
}

\author{
M.L.S. Marques ${ }^{1}$, M.F. Oliveira ${ }^{2}$, P.S. Pereira ${ }^{2}$ and M.R. Rocha ${ }^{2}$ \\ ${ }^{1}$ Instituto Federal Goiano - Campus Ceres, Ceres, Goiás, Brazil \\ ${ }^{2}$ Universidade Federal de Goiás, Escola de Agronomia, Avenida Esperança, Goiânia, Goiás, Brazil
}

\section{Summary}

The root-knot nematode Meloidogyne enterolobii is difficult to control due to its high aggressiveness and lack of resistant cultivars in the parasitized crops. Therefore, finding and characterizing sources of resistance to this nematode is an important task that may lead to new strategies for reducing its populations. The aim of the present study was to compare and describe the penetration and development of M. enterolobii in resistant and susceptible chili pepper genotypes (Capsicum spp.). Experiments were conducted under greenhouse conditions in a completely randomized design, in $\mathbf{2} \times \mathbf{5}$ factorial scheme, being factor A: two pepper genotypes (UFGCCH 24 - 'Bode Roxa' - resistant, and UFGCBA 3 - 'Cambuci' susceptible), and factor $B$ : five periods of evaluation $(7,14,21,28$, and 35 days after inoculation - DAI). The two genotypes were chosen based on a previous study that screened 72 Capsicum genotypes belonging to Universidade Federal de Goiás (UFG) collection. UFGCCH 24 is from Capsicum chinense species (CCH) and UFGCBA is a Capsicum baccatum species (CBA). At each period the roots were washed, stained and evaluated for nematode penetration and life cycle stage. At 35 DAI the nematode population density and reproduction factor (RF) were also evaluated by extraction from roots. Second stage juveniles (J2) penetrated the roots of resistant and susceptible genotypes, although in a lesser number in the resistant. M. enterolobii had its life cycle delayed within the resistant genotype roots resulting in a lower number of specimens. At 28 DAI, fully developed females were observed in the susceptible 'Cambuci', whereas in the resistant 'Bode Roxa' at 35 DAI, nematodes with the appearance of $\mathrm{J} 4$ were still observed, and some individuals differentiating into males. 'Cambuci' showed $\mathrm{RF}=1.82$ and higher gall index and egg mass index compared to 'Bode Roxa' that had RF $=0.67$.

Keywords

Capsicum chinense, $C$. baccatum, chili pepper, nematode life cycle, root-knot nematode

\section{Introduction}

Meloidogyne enterolobii Yang and Eisenback, 1983, is a species of root-knot nematode of great importance for several crops, including vegetables. As well as other Meloidogyne species, it is a polyphagous parasite that reproduces and feeds within plant roots and induce small to large galls or

\section{Significance of this study}

What is already known on this subject?

- Meloidogyne enterolobii parasitizes roots of tomatoes and peppers cultivars that carry the Mi gene that confers resistance to M. incognita and M. javanica.

What are the new findings?

- The chili pepper 'Bode Roxa' is resistant to M. enterolobii, by reducing J2 root penetration, delaying its development, and reducing the reproduction factor.

What is the expected impact on horticulture?

- The resistant genotype may be used as source of resistance in breeding programs, as a rootstock for other susceptible Capsicum species, or planted in infested areas.

root-knots. The life cycle comprises the eggs, four juvenile stages and adult male or female. Eggs are enclosed in gelatinous egg sacs that are usually deposited on the surface of galled roots. The first moult occurs within the egg giving rise to the second-stage juvenile (J2), which is the infective stage. Three other moults occur within the roots allowing the nematode to go through the stages J3, J4, and adults (Karssen and Moens, 2006). The species M. enterolobii was detected for the first time in Brazil in the states of Pernambuco and Bahia, causing severe damages in guava orchards (Carneiro and Almeida, 2001). In vegetables, it was detected for the first time in the state of São Paulo, parasitizing green pepper (Capsicum annuum) cultivar Silver and tomato (Solanum lycopersicum) cultivars 'Andrea' and 'Debora', all known to be resistant to M. incognita and M. javanica (Carneiro et al., 2006). This ability of $M$. enterolobii to parasite plants resistant to other species of Meloidogyne makes it a difficult-to-control nematode (Bitencourt and Silva, 2010). This species presents a wide polyphagia and highly aggressive behavior for most vegetable species in comparison to $M$. incognita and $M$. javanica (Pinheiro and Pereira, 2012).

Cultivars of tomato and pepper that have resistance to M. incognita, M. javanica and M. arenaria carry the Mi gene that gives the plant a hypersensitivity reaction (HR) causing histological changes, such as cell death near the infection site (Dropkin, 1969). This usually occurs 12 hours after attempted infection. However, the resistance conferred by the Mi-1 gene is unstable and can be compromised by soil temperatures above $28^{\circ} \mathrm{C}$ (Dropkin, 1969). In addition, there are species and races of Meloidogyne that have the ability to break the resistance conferred by the Mi gene, which makes 
it necessary to search for new sources of resistance, especially those that are effective against $M$. enterolobii.

Anatomical, physiological or biochemical characteristics may be responsible for lack of nematode penetration and/ or development in some plants (Rosso and Asmus, 2010). The expression of resistance genes may be the cause of the previous or post-infection existence of mechanisms triggering reactions that inhibit or reduce penetration or development after penetration (Wallace, 1973; Melo et al., 2011)

Reports on the penetration and development of nematodes in roots of Capsicum species, especially M. enterolobii, are unknown and may aid the identification of resistance mechanisms. In recent years, studies have been carried out in the search for sources of resistance to M. enterolobii in several crops, since the resistance of Capsicum to M. enterolobii is apparently mediated by genes other than those that confer resistance to other species and races of Meloidogyne (Melo et al., 2011). Currently, two intraspecific hybrid peppers (cvs. 'Silver' and 'Snooker') with resistance to $M$. incognita races 1, 2, 3 and 4 and $M$. javanica, a pepper cultivar 'BRS Sarakura' with resistance to $M$. incognita race 1 and M. javanica and four cultivars 'BRS Mari', 'BRS Moema', 'BRS Garça', and 'BRS Seriema', with resistance to M. javanica (Pinheiro et al., 2013) are commercially available. However, there is no information on commercial cultivars of Capsicum resistant to M. enterolobii.

The objective of the present study was to compare and describe the penetration, development and reproduction of M. enterolobii in roots of pepper genotypes resistant (UFGCCH 24 'Bode Roxa') and susceptible (UFGCBA 3 'Cambuci').

\section{Materials and methods}

The research was conducted under greenhouse and laboratory conditions at the geographic coordinates: $16^{\circ} 40^{\prime} 22^{\prime \prime} \mathrm{S}$ and $49^{\circ} 15^{\prime} 19^{\prime \prime} \mathrm{W}$ and average altitude of $730 \mathrm{~m}$, from September to October, 2016. Two pepper genotypes were chosen (Capsicum spp.) based on previous studies (Marques et al., 2019), which presented resistance and susceptibility to $M$. enterolobii, with RF equal to 0.08 (C. chinense - UFGCCH 24 'Bode Roxa') and 7.21 (Capsicum baccatum - UFGCBA 3 'Cambuci'). UFGCCH stands for Universidade Federal de Goiás, Capsicum chinense genotype 24 and UFGCBA 3 stands for Universidade Federal de Goiás, Capsicum baccatum genotype 3

The seeds were obtained from the Capsicum spp. seed collection of Federal University of Goiás. Sowing was done by a certified nursery and seedlings presenting four leaves were transplanted into black polyethylene plastic bags $(500 \mathrm{~mL})$, one seedling in each bag, containing a mixture of sterilized soil and sand (1:1). Fertilizers were not used due to the short period of the experiment.

The inoculum of $M$. enterolobii was obtained from a population extracted from Psidium guajava L. var. 'Paluma' and was kept in tomato (cultivar 'Santa Cruz Kada') plants under greenhouse. The identification and confirmation of the nematode species was performed by the analysis of the esterase phenotypes according to Carneiro and Almeida (2001). After fifteen days of transplanting the seedlings were artificially inoculated with $5.0 \mathrm{~mL}$ of suspension containing approximately 5,000 eggs and J2 of $M$. enterolobii per plot (one plant bag ${ }^{-1}$ ). Plants were watered daily by hand avoiding excess humidity. The average maximum, minimum and soil temperature during the period were, respectively, 38.03, 21.31 and 29.37 .
The experimental design was completely randomized in a $2 \times 5$ factorial scheme (two genotypes of Capsicum spp. $\times$ five evaluation periods) with three replications. When difference among evaluation timings was found the regression analysis was performed using logarithmic model.

Ten replicates of each genotype were added for evaluations at 35 days after inoculation (DAI) of fresh root mass (FRM), gall index (GI), egg mass index (EMI), nematode population density (eggs $+\mathrm{J} 2$ / $10 \mathrm{~g}$ of roots) and reproduction factor (RF).

The nematode penetration evaluation in the roots was carried out at 7, 14, 21, 28, and 35 days after inoculation (DAI), with three plants of each genotype being removed in each evaluation period. The plants were carefully removed, the aerial part discarded, and the roots washed in running water and weighed for fresh root mass (FRM). The roots were then stained by the acid fuchsin technique (Byrd et al., 1983) where the root fragments were soaked for four minutes in a $1.5 \% \mathrm{NaOCl}$ solution and subsequently drained and washed in tap water to remove all sodium hypochlorite and remained soaked in water for fifteen minutes. Thereafter, $1 \mathrm{~mL}$ of stain was added in about $30 \mathrm{~mL}$ of water and the material was boiled. The stain was prepared by diluting $3.5 \mathrm{~g}$ of acid fuchsin in $250 \mathrm{~mL}$ of acetic acid (99.7\%) and $750 \mathrm{~mL}$ of distilled water. After boiling for approximately thirty seconds, the root fragments were drained, allowed to cool and washed in running water to remove any excess stain. They were then placed in a $50 \mathrm{~mL}$ beaker containing glycerin acidified with two drops of hydrochloric acid and again brought to boil in order to clarify the roots. After bleaching, the fragments were placed in glycerin and stored at room temperature until the slides preparation for readings.

The evaluation was made by observation and counting of the nematodes present in the roots, using the optical microscope $(40 \times$ magnification). For this, the roots were arranged in petri plates to allow a total counting.

For photographic records of the nematodes roots of each Capsicum genotype, in each evaluation period, were pressed between two glass slides and taken to the optical microscope (100× magnification) with a digital camera coupled to capture images using the program LADEZ version 1.8.1.

At 35 DAI the plants were removed from pots, the shoots were discarded and the roots washed under running water and allowed to dry on paper towels. The roots were weighed on a digital scale $(0.001 \mathrm{~g}$ accuracy) and then stained with Floxin B (0.015\%), allowed to stand for 15-20 minutes, and then washed in running water to remove the residual stain from the roots. The egg masses external to the roots were colored, allowing the counting under a stereoscopic microscope. Gall index (GI) and egg mass index (EMI) were determined according to Taylor and Sasser (1978).

These same roots were used for nematode extraction following the technique of Coolen and D'Herde (1972). After extraction the nematodes were kept in 50-mL test tubes, for further counting using a Peters slide under an optical microscope (40× magnification). The population density (Pd) was calculated considering $10 \mathrm{~g}$ of roots (eggs and J2 / $10 \mathrm{~g}$ of root).

The total number of nematodes in each root system was considered the final population (Fp). The reproduction factor (RF) was obtained by the ratio between the final population (Fp) and the initial population (Ip) (RF = Ip/Fp), according to Oostenbrink (1966).

The data were submitted to the Lillieford and Bartlett test (Conagin et al., 1993) for continuous and discrete quantita- 


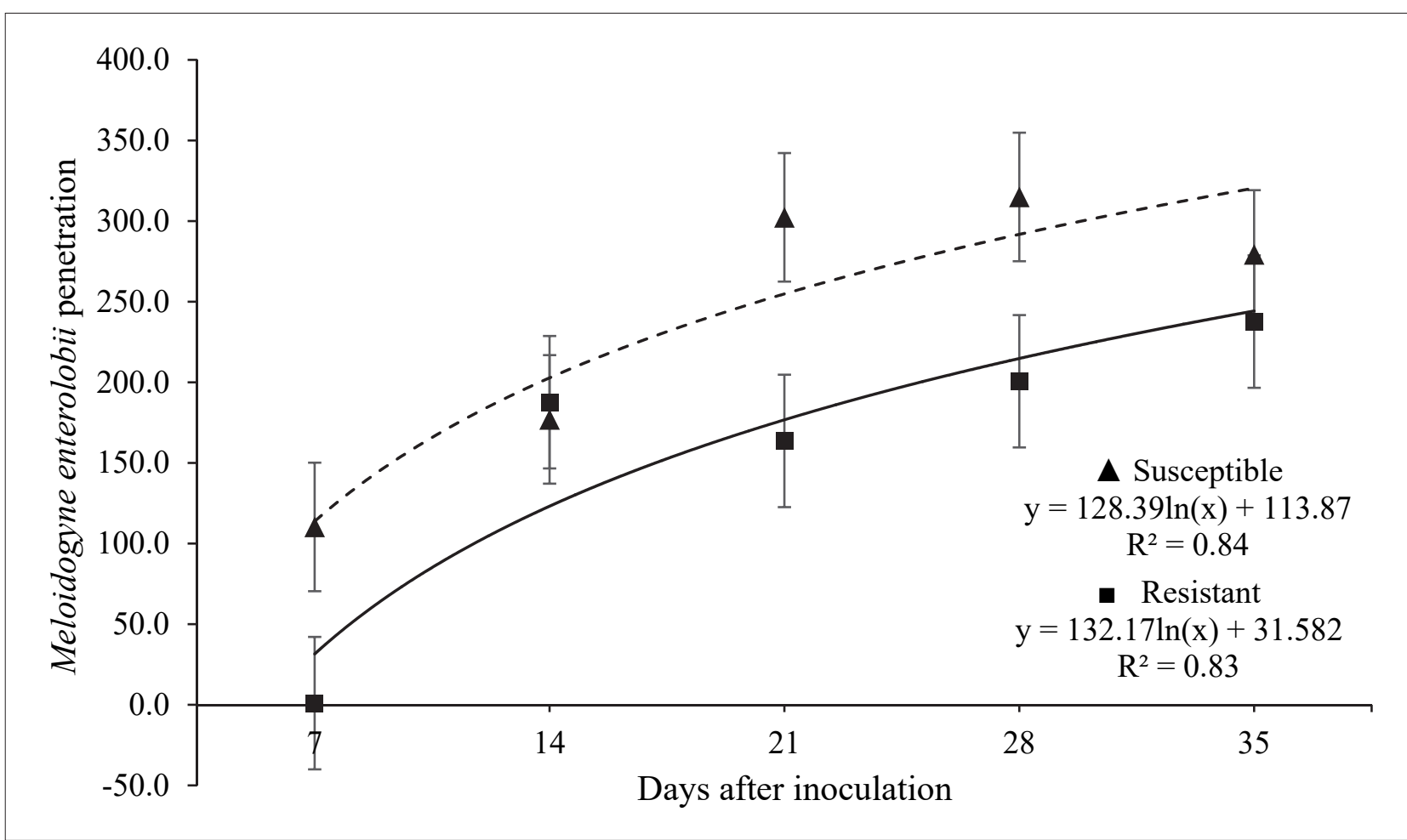

FIGURE 1. Penetration of Meloidogyne enterolobii in the roots of two Capsicum spp. genotypes (UFGCCH 24, 'Bode Roxa' Resistant, and UFGCBA 3, 'Cambuci' - Susceptible) at different sampling times (7, 14, 21, 28, and 35 days after inoculation).

tive dependent variables to test for normality and homoscedasticity. Data were submitted to analysis of variance using the Assistat version 7.7 computer program (Silva, 2017).

\section{Results}

The penetration of $M$. enterolobii in the roots of the two genotypes of Capsicum spp. in weekly evaluations, from seven to 35 DAI was higher in UFGCBA 3, 'Cambuci' at all times, compared to UFGCCH 24, 'Bode Roxa' (Figure 1). The number of specimens inside the roots of 'Cambuci' and 'Bode Roxa' increased over the period.

Root nematode extraction at $35 \mathrm{DAI}$ resulted in RF equal to 1.82 for 'Cambuci' and 0.67 for 'Bode Roxa', confirming their susceptibility and resistance behaviors, respectively (Table 1). In addition, 'Cambuci' also presented higher GI and EMI than 'Bode Roxa'. Population density, although not significantly different between the two genotypes, showed a percentage of reduction of $47.5 \%$ in the resistant genotype compared to the susceptible one (Table 1).

Along the evaluation period greater nematode penetra- tion and development in the roots of the susceptible genotype 'Cambuci' was observed (Figure $2-2,4,6,8,10$ ). The presence of second stage juveniles (J2) within the roots of both genotypes was observed at $7 \mathrm{DAI}$, but higher in the susceptible genotype (Figure 2-2). At 14 DAI third stage juveniles (J3) were found in the roots of the two genotypes (Figure 2-3, 4). However, larger, darker-colored nematodes in the 'Cambuci' susceptible genotype (Figure 2-4) are an indication of better fed individuals.

At 21 DAI it was already possible to see very clear differences between the genotypes, with the presence of a large number of well-developed individuals, with characteristics of J4 in 'Cambuci' (Figure 2-6), while in 'Bode Roxa', there was still the presence of poorly developed nematodes (deformed) in stage J3 (Figure 2 -5). These differences remained at $28 \mathrm{DAI}$, with the presence of fully developed females and rupture of the plant tissue in the susceptible genotype root (Figure 2-8). In the resistant genotype (Figure 2-7) specimens still in stages $\mathrm{J} 3$ and $\mathrm{J} 4$, and in smaller numbers, were observed.

TABLE 1. Reaction of two genotypes of Capsicum spp. to Meloidogyne enterolobii at 35 days after inoculation.

\begin{tabular}{lccccc}
\hline Capsicum genotypes & $\begin{array}{c}\text { Fresh root mass } \\
(\mathrm{g})\end{array}$ & Population density' & $\mathrm{RF}^{2}$ & Gall index & $\begin{array}{c}\text { Egg mass } \\
\text { index }\end{array}$ \\
\hline UFGCBA 3 'Cambuci' & $1.94 \pm 1.12 \mathrm{a}$ & $55,329 \pm 45,028 \mathrm{a}$ & $1.82 \pm 0.53 \mathrm{a}$ & $4.0 \mathrm{a}$ & $4.0 \mathrm{a}^{1}$ \\
UFGCCH 24 'Bode Roxa' & $1.37 \pm 0.66 \mathrm{a}$ & $29,019 \pm 31,958 \mathrm{a}$ & $0.67 \pm 0.30 \mathrm{~b}$ & $3.0 \mathrm{~b}$ & $3.0 \mathrm{~b}$ \\
\hline F test & $1.93^{\text {ns }}$ & $2.27^{\text {ns }}$ & $35.26^{* *}$ & $1 \times 10^{9^{* *}}$ & $1 \times 10^{\text {}^{* *}}$ \\
CV $(\%)$ & 16.83 & 43.76 & 34.76 & 0.0 & 0.0
\end{tabular}

Means from ten replications. Means followed by the same letter do not differ statistically (F Test, $5 \%)$. Data were transformed into $\sqrt{ }(x+1)$ for analysis.

${ }^{1}$ Number of nematodes per $10 \mathrm{~g}$ of roots.

${ }^{2}$ Reproduction factor.

*: Tukey test significance, $5 \%$; **: Tukey test significance, $1 \%$. 


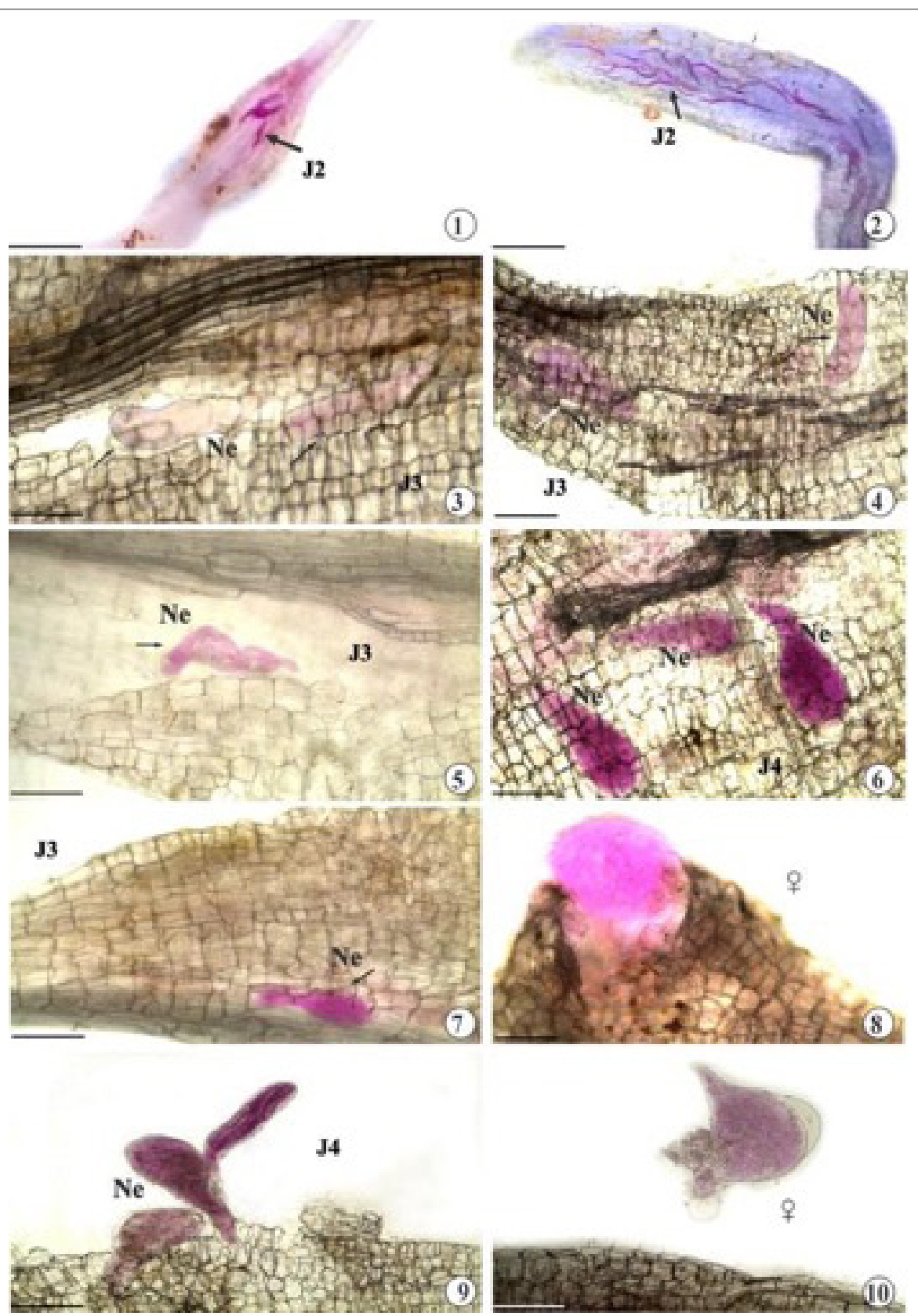

FIGURE 2. Roots of Capsicum spp. resistant (UFGCCH 24, 'Bode Roxa') and susceptible (UFGCBA 3, 'Cambuci') to Meloidogyne enterolobii at different sampling times showing the nematode development. 1, 3, 5, 7 and 9: roots of resistant genotype; 2, 4, 6, 8 and 10: roots of susceptible genotype; 1 and 2: 7 days after inoculation (DAI); 3 and 4: 14 DAI; 5 and 6: 21 DAI; 7 and 8: 28 DAI; 9 and 10: 35 DAI. Ne: nematode; J2: second-stage juvenile; J3: third-stage juvenile; J4: fourth-stage juvenile; 9 : adult female. Scale: $200 \mu \mathrm{m}$.

Fully mature and developed females were found at 35 DAI in 'Cambuci' (Figure 2-10), while in 'Bode Roxa', females were poorly developed. In addition, the presence of J4 differentiating into males (Figure 2-9) was noted, which is an unusual situation in the Meloidogyne genus.

\section{Discussion}

The comparison between the two pepper genotypes throughout the penetration evaluation period (Figure 1) and the reproduction factor (RF) evaluation (Table 1) confirmed the resistance behavior in UFGCCH 24, 'Bode Roxa' and susceptibility in UFGCBA 3, 'Cambuci'. Similar behavior of resistance to M. enterolobii in C. chinense (BGH 433 and BGH 4285 Pepper) was observed by Melo et al. (2011) in their study to identify lettuce, sweet potato, bean, tomato, and Capsicum genotypes with resistance to this nematode species.

Along the period of evaluation the number of nematodes penetrating the roots of the resistant genotype 'Bode Roxa' were always lower than that found on the susceptible 'Cambuci' (Figure 1). This shows that the resistance is not complete and although reducing $M$. enterolobii penetration the resistant genotype still allows some population development, which leads to the need of adding other alternatives when planning a nematode management program.

Juveniles of $M$. enterolobii inoculated in two genotypes of Capsicum spp. were attracted, penetrated the roots and migrated towards the vascular cylinder (Figure 2). However, there was less penetration in the resistant genotype 'Bode 
Roxa' than in the susceptible genotype 'Cambuci' (Figure $2-1,2$ ), indicating that possibly there is a preformed structural mechanism of resistance, such as higher root lignification that has restricted the penetration of juveniles. It is also possible that this resistance to penetration is conferred by the production of root exudates which repel J2 or are toxic to them (Rhode, 1972).

In the evaluations performed from the $14^{\text {th }}$ DAI on, it was observed that, in addition to penetration resistance, the UFGCCH 24, 'Bode Roxa' genotype decreased or hindered the development of M. enterolobii with a delay in the nematode development when compared to the susceptible genotype. It also led to a malformation of individuals (Figure 2-5, 7, 9). According to Huang (1985), some resistant plants may not present enough nutrients or substances essential for the nematode establishment, which would result in emigration and/or developmental delay. Based on this observation, it is possible that besides the hypersensitivity reaction (HR), other defense mechanisms associated with mechanical, physiological or biochemical barriers are developed by the plants (Silva et al., 1989), which did not necessarily cause the death of J2, but prevented from establishing a feeding site. The phenomenon of emigration as a result of the plant defense response was also observed previously in the coffee cultivar 'Apoatã' inoculated with M. incognita (Oliveira, 2006).

At 21 DAI the number of individuals in stages J3 and J4 were higher in the susceptible genotype, with only a few specimens in the roots of resistant genotype (Figure 2-5, 6). This suggests that the mechanism involved in resistance, besides delaying and consequently decreasing the amount of nematodes, also affects the establishment of these parasites in the root system. The presence of J3 and J4 in the resistant genotype indicates that the resistance reaction does not occur immediately after inoculation and does not prevent the initial establishment of $M$. enterolobii in this genotype.

Adult females of $M$. enterolobii in the egg laying phase were observed inside the roots within the feeding site at 28 DAI in the susceptible genotype ('Cambuci') (Figure 2-8). This shows that the nematodes in the roots of the susceptible genotype found favorable conditions for its development and multiplication. In the resistant genotype ('Bode Roxa'), at $28 \mathrm{DAI}$, we found nematodes in phases $\mathrm{J} 3$ and J4, and they were in smaller amounts than in 'Cambuci' (Figure 2 - 7). This indicates that there was damage or difficulties in the establishment and maintenance of the feeding site, which led to poor performance of the parasite in the resistant genotype. This persisted at $35 \mathrm{DAI}$, when the presence of individuals in the J4 phase was still observed and some individuals differentiated into males (Figure 2-9), which is rare in the Meloidogyne genus, and usually induced by stress, probably due to the lack of nutrients (Moura et al., 1993). It is known that the complete development of females and multiplication of the nematode depends on the formation of giant cells capable of nourishing the nematode throughout its cycle (Hussey, 1985; Abad et al., 2009). The females remain longer periods feeding in the roots while the males, as soon as becoming adults, stop feeding and leave the roots. Although of unusual presence of males, its only purpose is the reproduction (Moura et al., 1993). Thus, it is already proven the higher formation of males in stress situations, such as plant genetic resistance.

On the other hand, the presence of females, even in smaller numbers, was noted in the roots of the resistant genotype, showing that the resistance of this genotype (UFGCCH 24, 'Bode Roxa') is not complete. It is known that most resistance mechanisms are postinfectious, that is, root-knot nematodes
(M. incognita, M. arenaria, M. javanica, M. hapla) penetrate the roots, migrate in search of cells to establish the feeding site, but are impaired by the resistance genes $(M e 3$ gene in chili pepper, Mi1, Mi3 and Mi9 genes in tomato) (Williamson and Kumar, 2006).

According to Castagnone-Sereno et al. (2001) the resistance of $C$. annuum to $M$. javanica is conferred by the $M i$ gene. Peppers carrying the $M e 1$ gene may be resistant to $M$. incognita and M. javanica if the $M e 3$ gene is present in the same variety and may be susceptible to $M$. incognita. Gonçalves et al. (2014) verified the inefficiency of the $M e 7$ resistance gene, present in the $C$. annuum CM334 genotype, against $M$. enterolobii. The resistance and susceptibility of Capsicum spp. genotypes to nematodes could be related to the genes present in different species (Kiewnick et al., 2009; Melo et al., 2011). According to Dropkin (1969), this phenomenon usually occurs 12 hours after the attempt of establishment of the nematode inside the root, with occurrence of localized necrosis or hypersensitivity reaction (HR).

The $C$. chinense genotype UFGCCH 24 ('Bode Roxa') reacted with resistance to $M$. enterolobii, presenting lower levels of J2 penetration in the roots and developmental delay for the subsequent phases of J3, J4 and adult. In addition, it presented $\mathrm{RF}<1.0$ and lower number of nematodes throughout the evaluation period. Facing several reports of lack of resistance in commercial cultivars of Capsicum spp. to M. enterolobii, this research confirms the resistance of $C$. chinense - UFGCH 24 ('Bode Roxa') showing lower penetration and a delay on the development phases of the nematode. This indicates the need for further studies to identify the mechanisms and whether there are new genes conferring this resistance. In addition, this genotype can be used as source of resistance in breeding programs, as rootstock for other species of Capsicum spp. susceptible to M. enterolobii, or even for planting in areas infested by this nematode.

\section{References}

Abad, P., Castagnone-Sereno, P., Rosso, M.N., Engler, J.A., and Favery, B. (2009). Invasion, feeding and development. In Rootknot Nematodes, R.N. Perry, M. Moens, and J.L. Starr (eds.) (Wallingford, UK: CAB International), p. 163-181. https://doi. org/10.1079/9781845934927.0163.

Bitencourt, N.V., and Silva, G.S. (2010). Reprodução de Meloidogyne enterolobii em olerícolas. Nematologia Brasil. 34, 181-183. http://ccarevista.ufc.br/seer/index.php/ccarevista/article/view /3708/1244.

Byrd, D.W.T., Kirkpatrick, K., and Barker, R. (1983). An improved technique for clearing and staining plant tissues for detection of nematodes. J. Nematology 15, 142-143. https://www.ncbi.nlm.nih. gov/pmc/articles/PMC2618249/pdf/142.pdf.

Carneiro, R.G., Monaco, A.P.A., Moritz, M.P., Nakamura, K.C., and Scherer, A. (2006). Identificação de Meloidogyne enterolobii em goiabeira e em plantas invasoras, em solo argiloso, no Estado do Paraná. Nematologia Brasil., Campinas 30, 293-298. http://docentes.esalq.usp.br/sbn/ nbonline/ol\%20303/293-298\%20pb.pdf.

Carneiro, R.M.D., and Almeida, M.R.A. (2001). Técnica de eletroforese usada no estudo de enzimas dos nematoides de galhas para identificação de espécie. Nematologia Brasil. 25, 35-44. http:// docentes.esalq.usp.br/sbn/nbonline/ol\%20251/35-44\%20gr.pdf.

Castagnone-Sereno, P., Bongiovanni, M., and Djian-Caporalino, C. (2001). New data on the specificity of the root-knot nematode resistance genes $M e 1$ and $M e 3$ in pepper. Plant Breeding 120, 429433. https://doi.org/10.1046/j.1439-0523.2001.00637.x. 
Conagin, A., Nagqai, V., Igue, T., and Ambrósio, L.A. (1993). Efeito da falta de normalidade em testes de homogeneidade de variâncias. Bragantia 52, 173-180. https://doi.org/10.1590/S000687051993000200010 .

Coolen, W.A., and D'Herde, C.J.A. (1972). A Method for the Quantitative Extraction of Nematodes from Plant Tissue (Ghent: State Nematology and Entomology Research Station), 77 pp. https:// www.cabdirect.org/cabdirect/abstract/19722001202.

Dropkin, V.H. (1969). The necrotic reaction of tomatoes and other hosts resistant to Meloidogyne: reversal by temperature. Phytopathology 59, 1632-1637. http://agris.fao.org/agris-search/ search.do?recordID=US201301227107.

Gonçalves, L.S.A., Gomes, V.M., Robaina, R.R., Valim, R.H., Rodrigues, R., and Aranha, F.M. (2014). Resistance to root-knot nematode (Meloidogyne enterolobii) in Capsicum spp. accessions. Revista Agrária 9(1), 49-52. https://doi.org/10.5039/agraria.v9i1a3496.

Huang, C.S. (1985). Formation, anatomy and physiology of giant cells induced by root-knot nematodes. In An Advanced Treatise on Meloidogyne, Vol. 1: Biology and Control, J.N. Sasser, and C.C. Carter (eds.) (NCSU and USAID Cooperative Publication), p. 155-164. http://agris.fao.org/agris-search/search.do?recordID=US8743741.

Hussey, R.S. (1985). Host-parasite relationship and associated physiological changes. In An Advanced Treatise on Meloidogyne, Vol. 1: Biology and Control, J.N. Sasser, and C.C. Carter (eds.) (NCSU and USAID Cooperative Publication), p. 143-153. http://agris.fao.org/ agris-search/search.do;jsessionid=6B28BE34EF2FA65E2B2D 877FA4DAB162?request_ocale=ar\&recordID=US8743740\&query $=\&$ sourceQuery $=\&$ sortField $=\&$ sortOrder $=\&$ agrovocString $=\& a d-$ vQuery $=\&$ centerString $=\&$ enableField $=$

Karssen, G., and Moens, M. (2006). Root-knot Nematodes. In Plant Nematology, R.N. Perry, and M. Moens (eds.) (Wallingford, UK: CABI), p. 59-90. https://doi.org/10.1079/9781845930561.0059.

Kiewnick, S., Dessimoz, M., and Franck, L. (2009). Effects of the Mi-1 and the $N$ root-knot nematode - resistance gene on infection and reproduction of Meloidogyne enterolobii on tomato and pepper cultivars. J. Nematology 41, 134-139. https://www.ncbi.nlm.nih.gov/ pmc/articles/PMC3365310.

Marques, M.L.S., Chadud, J.V.G., Oliveira, M.F., Nascimento, A.R., and Rocha, M.R. (2019). Identification of chili pepper genotypes (Capsicum spp.) resistant to Meloidogyne enterolobii. J. Agric. Sci. 11, 165175. https://doi.org/10.5539/jas.v11n8p165.

Melo, O.D., Maluf, W.R., Gonçalves, R.J.S., Neto, A.C.G., Gomes L.A.A., and Carvalho, R.C. (2011). Triagem de genótipos de hortaliças para resistência a Meloidogyne enterolobii. Pesquisa Agropecuária Brasil. 46, 829-835. https://doi.org/10.1590/S0100$204 X 2011000800007$.

Moura, R.M., Davis, E.L., Luzzi, B.M., Boerma, H.R., and Hussey, R.S (1993). Post-infectional development of Meloidogyne incognita on susceptible and resistant soybean genotypes. Nematropica, Florida 23, 13. http://journals.fcla.edu/nematropica/article/view/64053.

Oliveira, D.S. (2006). Patogenicidade de populações de Meloidogyne incognita, proveniente de Minas Gerais e São Paulo, ao cafeeiro. Ph.D. thesis (Viçosa, MG, Brasil: Universidade Federal de Viçosa). http:// www.sbicafe.ufv.br/bitstream/handle/123456789/327/196289f. pdf? sequence $=1 \&$ isAllowed $=y$.

Oostenbrink, M. (1966). Major characteristics of the relation between nematodes and plants. Mededelingen Landbouwhogeschool 66, 1-46. https://books.google.com.br/books?hl=pt-BR\&l$\mathrm{r}=\& \mathrm{id}=6 \mathrm{JU} 3 \mathrm{AAAAIAAJ} \& \mathrm{oi}=\mathrm{fnd} \& \mathrm{pg}=\mathrm{PA} 8 \& \mathrm{dq}=$ Major + character istics+of+the+relation+between+nematodes+and+plants.+Mededelingen+Landbouwhogeschool+66:1-46.\&ots=MRi71XZgg$\mathrm{d} \&$ sig=v6C5gi0LoIWV3dqsWuR3DfTSxeg\#v=onepage \&q\&f=false.
Pinheiro, J.B., and Pereira, R.B. (2012). Produção de tomate para o processamento industrial. Embrapa, Brasília, DF 1, 243-260. http:// livraria.sct.embrapa.br/liv_resumos/pdf/00052450.pdf.

Pinheiro, J.B., Reifschneider, F.J.B., Pereira, R.B., and Moita, A.W. (2013). Reprodução de Meloidogyne spp. em Capsicum spp. Nematologia Brasil. 37, 20-25. http://docentes.esalq.usp.br/sbn/nbonline/ ol\%203712/20-25\%20co.pdf.

Rhode, R.A. (1972). The expression of resistance in plants to nematode. Ann. Rev. Phytopathol. 10, 233-252. https://doi.org/10.1146/ annurev.py.10.090172.001313.

Rosso, G.T., and Asmus, G.L. (2010). Imunidae de Pinhão-manso a Heterodera glycines. Nematologia Brasil. 34, 129-131.https://ainfo. cnptia.embrapa.br/digital/bitstream/item/27203/1/NematologiaBrasileira-Asmus.pdf.

Silva, F.A.S. (2017). ASSISTAT: Versão 7.7beta. http://www.assistat. com/.

Silva, G., Ferraz, S., and Santos, J.M. (1989). Atração, penetração e desenvolvimento de larvas de Meloidogyne javanica em raízes de Crotalaria spp. Nematologia Brasil. 13, 151-163. http://www.bdpa. cnptia.embrapa.br/consulta/busca?b=ad\&id=131236\&biblioteca=vazio\&busca=autoria:\%22SILVA,\%20G.\%20S.\%22\&qFacets=autoria:\%22SILVA,\%20G.\%20S.\%22\&sort=\&paginacao=t\&paginaAtu$\mathrm{al}=1$.

Taylor, A.L., and Sasser, J.N. (1978). Biology, identification and control of root-knot nematodes (Meloidogyne spp.) (Raleigh: North Carolina State University) 111 pp. http://citeseerx.ist.psu.edu/viewdoc/ download?doi=10.1.1.471.129\&rep=rep1\&type=pdf.

Wallace, H.R. (1973). Nematode Ecology and Plant Disease (New York: Crane and Russak) 228 pp. https://books.google.com.br/ books/about/Nematode_ecology_and_plant_disease.html?id=P_ rwAAAAMAAJ\&redir_esc=y.

Williamson, V.M., and Kumar, A. (2006). Nematode resistance in plants: the battle underground. Trends in Genetics 22, 396-403. https://doi.org/10.1016/j.tig.2006.05.003.

Received: Mar. 7, 2019

Accepted: Nov. 25, 2019

Addresses of authors:

M.L.S. Marques ${ }^{1}$, M.F. Oliveira ${ }^{2}$, P.S. Pereira ${ }^{2}$ and M.R. Rocha ${ }^{2, *}$ ${ }^{1}$ Instituto Federal Goiano - Campus Ceres, Caixa Postal 151, CEP 76300-000, Ceres, Goiás, Brazil

${ }^{2}$ Universidade Federal de Goiás, Escola de Agronomia, Avenida Esperança, s/n., Campus Samambaia, CEP:

74.690-900, Goiânia, Goiás, Brazil

* Corresponding author;

E-mail: darochamararubia@gmail.com

Tel.: 55-62-99687-1878 